\title{
THE RECRUDESCENCE OF PROPERTY RIGHTS AS THE FOREMOST PRINCIPLE OF CIVIL LIBERTIES: THE FIRST DECADE OF THE BURGER COURT*
}

\begin{abstract}
William W. Van Alstyne $\dagger$
The great and chief end, therefore, of men's uniting into commonwealths and putting themselves under government is the preservation of their property, to which in the state of nature there are many things lacking.

-John Locke

[T] he dichotomy between personal liberties and property rights is a false one. Property does not have rights. People have rights. The right to enjoy property without unlawful deprivation, no less than the right to speak or the right to travel, is in truth a "personal" right. *** In fact, a fundamental interdependence exists between the personal right to liberty and the personal right in property. Neither could have any meaning without the other. That rights in property are basic civil liberties has long been recognized.

-Lynch v. Household Finance Corp. ${ }^{2}$
\end{abstract}

I

Introduction: In Search of a Synecdoche

A "synecdoche" is a figure of speech which uses a less inclusive term in lieu of a more inclusive term. In addressing the work of the Supreme Court in relation to individual liberty during this past decade, it would obviously be helpful to have a synecdoche: some single word to stand in place of the Court's libertarian jurisprudence otherwise scattered among the several hundred opinions of the last ten years of U.S. Reports.

Despite the volume of published reviews of the Court's work, however, for a considerable time it seemed to me that no suitably accurate, single-word description could be found. It could not be located in the use of any one Justice's name, as an unhurried review of the Court's civil liberties decisions does not suggest that the results or the reasoning are characteristically marked by the constitutional jurisprudence of one dominant figure. Clearly we do not have an equivalent, for instance, of "The Marshall Court" in which, despite the great brilliance of other individuals such as Justice Story, it was nonetheless possible to speak usefully of a dominant jurisprudence conveniently

\footnotetext{
* Copyright $\odot 1980$ by William W. Van Alstyne.

$\dagger$ William R. Perkins and Thomas C. Perkins Professor of Law, Duke University.

1. J. Locke, Of the Ends of Political Society and Government, in Second Treatise of CiviL GovERNMENT (1690).

2. 405 U.S. 538,552 (1972)
} 
identified to the Chief Justice. Ostensibly, neither do we have a pattern of decisions that are sufficiently all-of-a-piece that the various civil liberties cases of the past decade can, with not unreasonable oversimplification, be captured in a single, conventional, political adjective or noun. This has not been a "radical" Court, surely, but neither has it been "reactionary" in its applications of the Bill of Rights. It does not even appear quite serviceable to denominate it a Court of "retrenchment." Rather, on first impression, it appears more eclectic and individuated with no strong single jurisprudential signature evident in either some general orientation of result (e.g., favoring the government or favoring the individual) or of analytic mode (e.g., favoring a textual literalism or favoring a "purpose" perspective of various constitutional clauses).

In matters of criminal procedure, there has undoubtedly been an arrest of rights and some actual diminution in safeguards previously thought to be secured in the Bill of Rights. ${ }^{3}$ In matters of religious freedom, prerogatives of free exercise have been rather generously construed ${ }^{4}$ albeit, as Professor Grey quite rightly observes, principally for claims of conventional virtue and of established morality. ${ }^{5}$ Insofar as individual liberty may be enhanced by the establishment clause, on the other hand, the results are assuredly more mixed: incentives have been newly furnished to sectarian establishments seeking financial relief through the public treasury ${ }^{6}$ and no formula has yet been devised to check the enactment of fundamentalist beliefs. In respect to freedom of speech and of the press, there has been at the least an arrest of the expansionary protections characteristic of the preceding decade ${ }^{7}$ and, in certain

3. See, e.g., Williams v. Florida, 399 U.S. 78 (1970) (twelve person jury not required in state criminal trials); Apodaca v. Oregon, 406 U.S. 404, and Johnson v. Louisiana, 406 U.S. 356 (1972) (less-than-unanimous jury verdicts sufficient in state criminal trials); Harris v. New York, 40I U.S. 222 (1971), Oregon v. Hass, 429 U.S. 714 (1975), and Rakas v. Illinois, 99 S. Ct. 421 (1978) (exclusionary rule of Miranda v. Arizona, 384 U.S. 436 (1966) restricted); Stone v. Powell, 428 U.S. 465 (1976) and United States v. Calandra, 414 U.S. 338 (1971) (exclusionary rule further restricted); Kirby v. Illinois, 406 U.S. 682 (1972) (due process requisites of suspect identification, United States v. Wade, 388 U.S. 218 (1967) limited); United States v. Martinez-Fuerte, 428 U.S. 543 (1976) and Smith v. Maryland, 99 S. Ct. 2577 (1979) (fourth amendment search warrant requirements held inapplicable); Scott v. Illinois, 440 U.S. 367 (1979) (jury trial requirements of Argersinger v. Hamlin, 407 U.S. 25 (1972) reduced).

4. See, e.g., Wisconsin v. Yoder, 406 U.S. 205 (1972). Cf. Prince v. Massachusetts, 321 U.S. 158 (1944).

5. Thus, in Yoder, Chief Justice Burger extolled the sturdy, agrarian, self-reliant virtues of the Amish and declared:

It cannot be overemphasized that we are not dealing with a way of life and mode of education by a group claiming to have recently discovered some "progressive" or more enlightened process for rearing children for modern life.

406 U.S. at 235 . He concludes that "probably few other religious groups or sects could make" the same sort of "convincing showing" sufficient to render the compulsory attendance law invalid as applied to the Amish. Id. at 236.

6. See, e.g., Wolman v. Walter, 433 U.S. 229 (1977), Roemer v. Board of Public Works, 426 U.S. 736 (1976), and Hunt v. McNair, 413 U.S. 734 (1973) (varieties of state financial assistance to distinctly sectarian schools sustained).

7. See, e.g., Time, Inc. v. Firestone, 424 U.S. 448 (1976) and Gertz v. Robert Welch, Inc., 418 
respects, a net diminution in the boundary of the free speech clause for those without money to pay ${ }^{8}$ as against the enlarged prerogatives of those with the means to advertise. ${ }^{9}$ The nascent revolution of Millian autonomy has been altogether checked and the "penumbras" of rights "emanating" from the ninth amendment have been reined in. ${ }^{10}$ Most conspicuously, the procedural due process explosion in administrative law has bumped up against a very tough doctrinal barrier: entitlements to some kind of hearing are newly dependent upon a fulcrum of "property," and, evidently, what constitutes property depends upon the pleasure of the state. ${ }^{11}$

On the other hand, the Bivens case ${ }^{12}$ - which held that the Bill of Rights provides private causes of action-is unquestionably one of the most significant positive-law developments in the entire history of the Bill of Rights. Though it appeared early in the decade, it was nonetheless a feature of this decade of constitutional law. Similarly, the abortion decisions were also civil liberties decisions of the $1970 \mathrm{~s}^{13}$ Judging them merely from the criticism levelled by moderates of constitutional law alone, ${ }^{14}$ they may reasonably be described as resting far from a conservative view of the Bill of Rights. Finally,

U.S. 323 (1974) (libel standards eased); Gannet Co. v. DePasquale, 99 S. Ct. 2898 (1979), Houchins v. KQED, 438 U.S. 1 (1978), and Lehman v. City of Shaker Heights, 418 U.S. 298 (1974) (speech-access restricted).

8. See, e.g., Greer v. Spock, 424 U.S. 828 (1976) (handbilling on government property limited); Hudgens v. NLRB, 424 U.S. 507 (1976) (picketing on private property limited); Miami Herald Pub. Co. v. Tornillo, 418 U.S. 241 (1974) (newspaper right-of-reply statute held invalid). Cf. Flower v. United States, 407 U.S. 197 (1972) (handbilling on military base protected); Amalgamated Food Employees Union v. Logan Valley Plaza, 391 U.S. 308 (1968) (picketing on private property protected); Red Lion Broadcasting Co. v. FCC, 395 U.S. 367 (1969) (FCC right-of-reply regulation sustained).

9. See, e.g. First National Bank v. Bellotti, 435 U.S. 765 (1978) (corporate funds to campaign against ballot issues protected); Buckley v. Valeo, 424 U.S. 1 (1976) (restrictions on personal electioneering expenditures invalidated); Virginia State Bd. of Pharmacy v. Virginia Citizens Council, Inc, 425 U.S. 748 (1976), and Bates v. State Bar, 433 U.S. 350 (1977) (commercial advertising protected).

10. See, e.g., Doe v. Commonwealth's Attorney, 425 U.S. 901 (1976), aff'g mem., 403 F. Supp. 1199 (E.D. Va. 1975); Wainwright v. Stone, 414 U.S. 21 (1973). Chief Justice Burger provides a nearly explicit denunciation in Paris Adult Theatre l v. Slaton, 413 U.S. 49 (1973). It is fair to note, by way of passing interest, that parts of Holmes's famous dissenting opinion in Lochner $v$. New York, 198 U.S. 45 (1905) are similar. See, e.g., id. at 75 where Holmes derides "[t ]he liberty of the citizen to do as he likes so long as he does not interfere with the liberty of others to do the same," as "a shibboleth for some well-known writers."

11. See, e.g., Meachum v. Fano, 429 U.S. 215 (1976); Bishop v. Wood, 426 U.S. 341 (1976); Board of Regents v. Roth, 408 U.S. 564 (1972).

12. Bivens v. Six Unknown Named Agents, 403 U.S. 388 (1971). The original implications of the case are described in Dellinger, Of Rights and Remedies: The Constitution as a Sword, 85 HARV. L. REv. 1532 (1972). An excellent recent review of its operational limitations is provided by a Note, "Damages or Nothing"-The Efficacy of the Bivens-Type Remedy, 64 CoRnELL L. REv. 667 (1979).

13. Roe v. Wade, 410 U.S. 113 (1973); Doe v. Bolton, 410 U.S. 179 (1973). But see the retrenchment more recently evident in Maher v. Roe, 432 U.S. 464 (1977).

14. See, e.g., Ely, The Wages of Crying Wolf: A Comment on Roe v. Wade, 82 YALE L.J. 920 (1973). 
if one judges these matters not alone from pure constitutional decisions, (i.e., those involving interpretations of particular clauses in the Constitution itself), but from the perspective of practical recourse against government infringements of those liberties, the statutory rendering of our most important Civil Rights Act (42 U.S.C. $\S 1983$ ) in the Monnell ${ }^{15}$ case is an exceedingly liberal opinion-providing money recourse against the deep pockets of cities and counties for violations of fourteenth amendment liberties.

This artless, thumbnail, skimming review is not meant to be complete by any means. To the contrary, I recognize that it but cavalierly restates what has been more systematically reviewed elsewhere. I have reiterated it only to demonstrate the difficulty, and perhaps the foolishness, of looking for a synecdoche-a lesser inclusive term useful to represent the more inclusive term of the Supreme Court and liberties during the preceding decade of constitutional law.

One may try other kinds of comparisons, but they, too, lack both novelty and importance. In comparison with the last decade of the Warren Court, for instance, without doubt the work of this decade has been less aggressive. In comparison with nearly any other decade of Bill of Rights interpretations, on the other hand, this last one is probably virtually as generous as any previous ten years of decisions (and, of course, the "jurisprudence" of the Warren Court has been the object of intense criticism). In the thoughtfulness, care, and professional excellence of the Justices, so close are we to each decision as it comes down that our own parsing of its logic prematurely leads us to the supposition that the members of this court may somehow be less learned, less careful, or less judicious in superintending the Constitution than their predecessors. I personally do not think that this is so. To the contrary, I am inclined to believe that with only a few exceptions of the past, the ability, acuity, and detachment of the twelve Justices who have served since 1969 will, on sober comparison, overall compare very well. The well publicized voyeurism of The Brethren, ${ }^{16}$ incidentally, may be unintentionally instructive that there is nothing fundamentally amiss on the Court in this regard. Despite myriad personal revelations and despite the glimpses of private utterance and of unkind epithet, it is interesting that no scandal, no single instance of corruption, no incident of wrongdoing was unearthed. Even more, the revealed maneuvers of one Justice to influence another, to secure opinion-writing prerogatives, etc., are inadvertently reassuring: the Judges evidently care a great deal about their work and they do not regard the adjudication of constitutional law lightly. If studies of other departments of our national government were so ultimately empty of disturbing findings as were the best investigative efforts

15. Monell v. Department of Social Services, 436 U.S. 658 (1978).

16. B. Woodward \& S. Armstrong, The Brethren (1979). 
of Woodward and Armstrong into the Supreme Court, I do not think we would feel embarrassed but, instead, rather surprised.

For these reasons, I have found it exceedingly difficult to discern something distinctive or doctrinally telegraphic in the civil liberties adjudications of the past decade-with one exception. Finally, yet still by way of introduction, I want to identify that exception.

The "liberties" mentioned in the preceding thumbnail review include most of those individual liberties in vogue in contemporary conversation: freedom of speech, of the press, of religion; freedom of personal life style, freedom from intrusions by government; freedom from arbitrary modes of determining one's fate (whether in civil or in criminal proceedings). These are matters which, in a political context, we might associate with the resolute commitments of organizations like the American Civil Liberties Union with its informal motto that its sole client is the Bill of Rights-liberal political concerns of expression, privacy, fair hearings, and the franchise. They are, as well, of course, the modes of liberty most stressed by the Warren Court.

The difference I see that most nearly distinguishes an entire pattern of decisions and of doctrinal development re-emerging within the past decade from those that immediately preceded it, however, is not revealed in comparing recent decisions with preceding ones in the unidimensionality of this comparison alone. It is, rather, by considering a larger group of cases and by relating them to a different, tighter, more conservative view of liberty: liberty as security of private property; liberty as freedom of entrepreneurial skill; liberty from the impositions of government and of third parties from disposing of "one's own." Liberty, in brief, more in the mode of John Locke ${ }^{17}$ and of Adam Smith ${ }^{18}$ and somewhat less in the mode of John Mill ${ }^{19}$ (or of John Rawls). ${ }^{20}$ To that end, I shall speak briefly to what I think does represent the basic (albeit still very incomplete) change of direction that marks the "liberty" decisions of the preceding decade: the reemergence of the rights of property.

\section{II}

\section{Revitalizing the "Old" Constitution and \\ ENTREPRENEURIAL LIBERTY}

I mean to touch upon this subject very lightly, but it nonetheless does bear upon our subject and possesses a contextual significance of its own. The preoccupation of recent times almost exclusively with the Bill of Rights and with the fourteenth amendment has tended to suppress the recollection that at

\footnotetext{
17. J. Locke, Second Treatise of Civil Governmen't (1690).

18. A. Smith, The Wealth of Nations (1776)

19. J. Mill, ON Liberty (1859).

20. J. Rawls, A Theory of Justice (1971). Cf. R. Nozick, Anarchy, State and Utopia (1974)
} 
least certain kinds of significant "liberty" were shielded by the Constitution of 1789. The ban on state laws impairing the obligation of contracts was one of these, ${ }^{21}$ even as reflected in the famous Dartmouth College case. ${ }^{22}$ The interstate privileges and immunities clause in Article $I V^{\mathbf{2 3}}$ derived from the free trade clause of the Articles of Confederation, and expounded in Corfield $v$. Coryell ${ }^{24}$ was another. The exclusionary implications of the commerce clause, construed in Gibbons $v$. Ogden ${ }^{25}$ as per se disallowing either discriminatory or unreasonably burdensome state interferences within a nationwide free trade zone, is of course yet another. The subsequent enactment of the "takings" clause, i.e., the eminent domain provision of the fifth amendment, ${ }^{26}$ is a fourth.

Each of these, especially in close relation with the others, quite genuinely "nationalized" the protection of certain private rights and the entrepreneurial liberties: principally, the conjunction between John Locke's Second Treatise of Civil Government (published in 1690) and Adam Smith's The Wealth of Nations (published in 1776). Locke's influential Treatise declared that the chief end of civil government is to protect the security of private property virtually as an extension of oneself. The second, Adam Smith's durable volume, stressed the superior efficiency of private exchange and of a relatively untrammeled market in satisfying individual wants.

Fifteen years ago, in an excellent article, William Howard Mann devoted an unhurried 128-page review to the manner in which the Marshall Court protected these important economic freedoms ${ }^{27}$ and I will not presume to summarize those developments still again. Rather, I mean but to observe that at least in comparison with recent decades past, the current decade has brought back from relative obscurity some of these clauses and some of this sense of commercial liberty. For instance, after a long eclipse signalled vividly in the Great Depression by the Blaisdell case, ${ }^{28}$ the provision against laws impairing obligations of contracts has been revived and twice applied against abridging state legislation. ${ }^{29}$ Similarly, in at least three instances state laws

21. "No State shall .. pass any .. Law impairing the Obligation of Contracts . . ." U.S Const. art. I. \$10, cl. 1 .

22. Trustees of Dartmouth College v. Woodward, 17 U.S. (4 Wheat.) 518 (1819).

23. "The Citizens of each State shall be entitled to all Privileges and Immunities of Citizens in the several States." U.S. Const. art. 4, \$2, cl. 1.

24. 6 Fed. Cas. 546, No. 3,230 (C.C.E.D.Pa., 1823).

25. 22 U.S. (9 Wheat.) 1 (1824).

26. "[N]or shall private property be taken for public use without just compensation." U.S. Const. amend. S.

27. Mann, The Marshall Court: Nationalization of Private Rights and Personal Liberty from the Authority of the Commerce Clause, 38 Indiana L.J. 117 (1963).

28. Home Building \& Loan Association v. Blaisdell, 290 U.S. 398 (1934); see also El Paso v. Simmons, 379 U.S. 497 (1965).

29. United States Trust Co. v. New Jersey, 431 U.S. 1 (1977): Allied Structural Steel Co. v. Spannaus, 438 U.S. 234 (1978). 
rather egregiously favoring local economic interests from fairer competition within a national market have been held invalid pursuant to the interstate privileges and immunities clause. ${ }^{30}$ And again, in several instances the Court has not been content to wait for Congress to act against substantial stateimposed burdens on interstate commerce justified by rather marginal local interests, but has itself applied the commerce clause to hold those regulations unconstitutional. ${ }^{31}$

Even the "takings" clause of the fifth amendment has experienced a recent revival in behalf of private property and entrepreneurial freedom. After a very close contest within the Court in which the clause was held not to be offended in the Penn Central case, ${ }^{32}$ a decision in December 1979, did hold the clause applicable to forbid the government from imposing an-unpaid-for public servitude upon a valuable commercial development in Hawaii. ${ }^{33}$

None of these is a "revolution" in constitutional law and none is the least earth shattering either by itself or in combination with the other cases linked by common themes of private property, competition, a national market, and entrepreneurial freedom. Insofar as they tend to show that some of the "old" liberties have not yet wholly yielded to the social impulse to regulate or to redistribute, however, they are not unimportant. They do, moreover, seem to me to suggest a difference in emphasis from the more personal, more "Millian," liberties best known during the preoccupations of the Warren Court-as they also provide a context for what has become of those less property-bound liberties during the past several years. Indeed, for reasons I now intend to examine at greater length, I think these cases are circumstantially significant, furnishing a renewed emphasis upon entrepreneurial rights as an important civil liberty of the nineteen-seventies.

III

The Enlargement of Private Property AND The Atrophy of Liberty for Those Who LACK IT

On November 13, 1979, the Supreme Court set down, for full briefing and for oral argument, a case with the unprepossessing title of Pruneyard Shopping Center v. Robins. ${ }^{34}$ Regardless of Pruneyard's eventual disposition on

30. Hicklin v. Orbeck, 437 U.S. 518 (1978); Austin v. New Hampshire, 420 U.S. 656 (1975); Gordon v. Committee on Character \& Fitness, 48 N.Y. 2d 266, 397 N.E. 2d 1309, 422 N.Y.S.2d 641 (1979) (New York statute requiring proof of residency of six months prior to admission to the State Bar held unconstitutional as violative of federal interstate privileges and immunities clause. $C f$. Baldwin v. Fish and Game Comm'n, 436 U.S. 371 (1978).

31. See, e.g., Hughes v. Oklahoma, 44l U.S. 322 (1979); Raymond Motor Transportation, Inc. v. Rice, 434 U.S. 429 (1978); Hunt v. Washington State Apple Advertising Comm'n, 432 U.S. 333 (1977); Allenburg Cotton Co. v. Pittman, 419 U.S. 20 (1974).

32. Penn Central Transportation Co. v. New York, 438 U.S. 104 (1978).

33. Kaiser Aetna v. United States, 100 S. Ct. 383 (1979).

34. 48 U.S.L.W. 3319. 
the merits, ${ }^{35}$ the fact that the Court regarded the questions pressed by the petitioner in this case as substantial constitutional questions is immensely instructive of several judicial changes wrought during this most recent decade. The message they convey is both Lockeian and Lochnerian. They represent the recrudescence of libertarian thought that identifies liberty with private property, liberty with prerogatives of property-to exclude from it, to contract with reference to it, to identify it as part of oneself. Burrowed within the runways of other decisions of this decade, moreover, is a closely related message: that private property is once again not merely important and often sufficient to assert one's essential liberty; it may also be a necessary condition to the practical realization of that liberty.

In the not-distant past, not to have private property was quite frequently fatal to one's abstract freedoms. One may have had an abstract freedom of speech. To exercise it, however, he must stand in some place or speak over some medium. If he had no front porch of his own, he could not, on that account commandeer his neighbor's. Neither could he commandeer the state's. For the prevailing view, very well represented in an early decision by Justice Holmes, was that property under government ownership carried with it exclusionary prerogatives fully equivalent to those possessed by private parties. ${ }^{\mathbf{3 6}}$ As long as the state merely cordoned off its own property, reserving public access for certain purposes only, and uniformly barring all persons equally from access for any other purposes, it was no more vulnerable to trespasses than a private owner.

Private property, its acquisition, ownership, and disposition, was thus the pivot of civil liberties. Though Holmes dissented in Lochner $v$. New York, aphoristically observing that "[t]he fourteenth amendment does not enact $\mathrm{Mr}$. Herbert Spencer's Social Statics," ${ }^{37}$ as the author of the Supreme Court's opinion in Pennsylvania Coal Co. v. Mahon ${ }^{38}$ and as the judge who denied that the state as property owner has fewer exclusionary prerogatives than private owners ${ }^{39}$ he did not quite deny that the Constitution may have enacted a system predisposed to a property theory of civil liberties. A great deal of this point of view has now returned. The renewed emphasis upon private property greatly helps, I believe, to fit together a significant number of otherwise disparate "civil liberties" cases.

35. It is possible that the merits will ultimately not be addressed at all; the Court postponed further consideration of the question of jurisdiction until after full hearing on the merits. See 48 U.S.L.W. at 3322 (Nov. 13, 1979).

36. Commonwealth v. Davis, 162 Mass. 510, 511,39 N.E. 113 (1895), aff'd, 167 U.S. 43 (1897): "For the legislature absolutely or conditionally to forbid public speaking in a highway or public park is no more an infringement of the rights of a member of the public than for the owner of a private house to forbid it in his house."

37. Lochner v. New York, 198 U.S. 45, 75 (1905).

38. 260 U.S. 393 (1922).

39. See note 37 , supra. 
The Pruneyard Shopping Center, ${ }^{40}$ in Santa Clara, California, attracts 25,000 customers daily to its twenty-one acres containing sixty-five shops, ten restaurants, a cinema, walkways, and a plaza. Michael Robins, a Santa Clara County schoolboy, sought to gather signatures from people frequenting the mall. His petition expressed opposition to a recent United Nations Resolution which identified Zionism with racism. Robins intended to send his petition to the President of the United States, evidently as some indication that many persons, himself included, did not agree with the United Nations. His activity was apparently nondisruptive and reasonably well received by Pruneyard patrons. Nonetheless, he was required to leave the shopping center on order of a security guard responsible for the enforcement of a company policy forbidding any expressive activity anywhere within the mall. Robins sought recourse to the California courts, to determine whether he might re-enter the mall to canvass for his petition.

Interestingly, he did not rely upon the first or the fourteenth amendments' guarantees of free speech, peaceable assembly, or rights of petition. He could not do so, because a decision by the Supreme Court issued in $1968^{41}$ (by the Warren Court) had first been severely restricted by a subsequent decision in $1972^{42}$ and then flatly overruled by a more recent decision in $1976 .^{43}$ The 1968 decision, a shopping center case, was derived from a prior decision of 1946, Marsh $v$. Alabama, ${ }^{44}$ which was derived from a prior decision of 1946, Thornhill $v$. Alabama, ${ }^{45}$ where nondisruptive picketing had been held to be constitutionally sheltered although it occurred within the boundary of privately-held land. The 1976 decision restored the exclusivity of private property prerogatives, finding insufficient verisimilitude between large, corporately-held shopping plazas and either public parks or complete company towns, for free speech freedoms to be applicable. The fact that Robins could make no argument based on the fourteenth or first amendments, whereas but two or three years earlier a similarly situated individual could almost surely have made a successful argument, is itself declarative of one significant judicial trend.

Without reliance upon those amendments, Robins did, however, rely upon a provision in the California Constitution, a provision phrased somewhat differently from the first amendment. ${ }^{46}$ In a four-to-three decision, the

40. The following factual description of the case is taken from the California Supreme Court opinion, 23 Cal. 3rd 909, 153 Cal. Rptr. 854, 592 P.2d 341 (1979).

41. Amalgamated Food Employees Union v. Logan Valley Plaza, 391 U.S. 308 (1968).

42. Lloyd Corp. v. Tanner, 407 U.S. 551 (1972).

43. Hudgens v. NLRB, 424 U.S. 507 (1976).

44. Marsh v. Alabama, 326 U.S. 501 (1946).

45. Thornhill v. Alabama, 310 U.S. 88 (1940).

46. Calif. Const., Art. I, \& 2: "Every person may freely speak, write and publish his or her sentiments on all subjects, being responsible for the abuse of this right. A law may not restrain or 
California Supreme Court agreed that the state constitutional provision was applicable to the shopping center, given its quasi-public characteristics, the virtual disappearance of any traditional downtown area as a place of common resort, and the nondisruptive character of Robins's activity. This, too, is not uninstructive respecting developments in civil liberties within the past decade: quite generally, as decisions from the Supreme Court have rebuffed or withdrawn previously-existing "rights," a number of state courts have reinvigorated moribund portions of their respective state constitutions to re-establish the line of protection under state law. ${ }^{47}$ There was, in this respect as well, nothing newly remarkable in the California Supreme Court's treatment of the case.

What is remarkable, however, is that the case did not end here as one might suppose that it would. The meaning and applicability of the California Constitution being an issue of state law within the exclusive and final determination of that state's own highest court, one would suppose that no federal question would be present and thus there would be no basis for appeal from that court to the Supreme Court of the United States. ${ }^{48}$ That reasoning assumes a great deal; it assumes that the liberty of private property is not sufficiently entrenched as to be protected by the fourteenth amendment from limitations imposed by a state constitution enabling third parties to come upon it for purposes of nondisruptive petitioning, at least when the property (as in this case) is otherwise open to public use, corporately-held, commercial in character, and functionally very much like a traditional center-of-town. In agreeing to hear Pruneyard, however, the Supreme Court now regards that question to be a substantial one. The questions framed for review are precisely those which I have identified . ${ }^{49}$

This change of "questions" within a decade is breathtaking. When I was a

abridge liberty of speech or press." (Quoted in Robins v. Pruneyard Shopping Center, 153 Cal. Rptr. 854, 859, 23 Cal. 2d 899, 908 (1979)).

47. See Howard, State Courts and Constitutional Rights in the Day of the Burger Court, 62 VA. L. Rev. 873 (1976). Justice Brennan has personally urged such developments. Brennan, State Constitutions and the Protection of Individual Rights, 90 HaRv. L. REv. 489 (1977).

48. See, e.g., Herb v. Pitcairn, 324 U.S. 117 , 125-26 (1945); Fox Film Corp. v. Muller, 296 U.S. 207 (1935): Murdock v. City of Memphis, 87 U.S. (20 Wall.) 590, 626 (1875).

49. (1) Does owner of private shopping center that has not been dedicated to public use and that is not functional equivalent of municipality have property right under Fifth and Fourteenth Amendments to prohibit non-business-related petitioning on premises of center when persons who wish to engage in such petitioning have other adequate and effective channels of communication in area?

(2) Does owner of private shopping center that has not been dedicated to public use and that is not functional equivalent of municipality have free speech right under First and Fourteenth Amendments to prohibit non-business-related petitioning on premises of center, when persons who wish to engage in such petitioning have other adequate and effective channels of communication in area?

"Questions presented," 48 U.S.L.W. 3319 (Nov. 13, 1979) 
Stanford law student in the mid-1950s, the question posed to me by Phil Neal in our course on constitutional law was one raised by the company town case of Marsh $v$. Alabama;50 namely whether the first and fourteenth amendments would secure some degree of third party free speech in the newly-planned Stanford shopping center. Professor Neal appeared to imply that presumably those amendments would apply and events in the sixties seemed to make him an excellent prophet. The question now posed is dramatically different: whether it unconstitutionally abridges property rights insofar as, by force of state constitutional law, some degree of third party free speech is allowed at all. Regardless of the outcome on the merits in the Supreme Court, the resemblance to Lochner ${ }^{51}$ (and to cases predating Euchid $v$. Ambler) ${ }^{52}$ is not very strained. In the context of the decision of but a few weeks ago, holding that the imposition of a public servitude on a commercially-developed private harbor in Hawaii constituted an uncompensated "taking" of the property in violation of the fifth amendment, ${ }^{53}$ the grant of review in the Pruneyard case is extremely telegraphic.

The linkage of free speech with private property is made clearer in other cases as well. In Pruneyard, the shopping center will argue in the Supreme Court not merely that substantive due process precludes the state from subjecting its property to forum uses by others; it is arguing also that its right to use its property in this (exclusionary) respect is also an aspect of the corporation's own freedom of speech-and thus the California Supreme Court is twice wrong in what it did. ${ }^{54}$ The claim is no longer a frivolous one; an entire line of decisions emergent in the seventies provides excellent ground for the shopping center argument which links "speech uses" of private property, even in a wholly commercial setting, with increasingly-protected first amendment prerogatives of business enterprise. One such line of cases is that which has overruled Valentine $v$. Chrestensen ${ }^{55}$ and has brought entrepreneurial commercial advertising prerogatives within the bounds of the first amendment. ${ }^{56}$ Closely related is the 1978 decision in First National Bank $v$. Belotti, ${ }^{57}$ invalidating a

\footnotetext{
50. See note 43 , supra.

51. See note 36 , supra.

52. Village of Euclid v. Ambler Realty Co., 272 U.S. 365 (1926).

53. See note 34 , supra.

54. See the second question presented in the case, note 49, supra.

55. 316 U.S. 52 (1942).

56. See Bates v. State Bar, 433 U.S. 350 (1977); Virginia State Board of Pharmacy v. Virginia Citizens Consumer Council, Inc., 425 U.S. 748 (1976); Bigelow v. Virginia, 421 U.S. 809 (1975). For refinements, see, e.g., Ohralik v. Ohio State Bar Assn., 436 U.S. 447 (1978); In re Primus, 436 U.S. 412 (1978); National Society of Professional Engineers v. United States, 435 U.S. 679 (1978); Young v. American Mini Theatres, 427 U.S. 50 (1976); Pittsburgh Press Co. v. Pittsburgh Commission on Human Relations, 413 U.S. 376 (1973); Capital Broadcasting Co. v. Mitchell, 333 F. Supp. 582 (D.D.C. 1971), aff'd without opinion sub nom. Capital Broadcasting Co. v. Acting Attorney General Kleindienst, 405 U.S. 1000 (1972).
}

57. 435 U.S. 765 (1978). 
state law forbidding commercial corporations from spending corporate funds to influence ballot issues. Connected as well, surely, is that part of Buckley $v$. Valeo ${ }^{58}$ decided in 1976 , invalidating spending restrictions imposed upon one's own money or one's own resources respecting election to office or political issues at large.

It is difficult to avoid the impression simultaneously that "property" made at least part of the difference in the opposite outcomes of the two principal "right of reply" cases of the past decade. In Red Lion Broadcasting, ${ }^{59}$ a unanimous Court sustained a federal regulation compelling a privately-owned radio station to furnish cost-free reply time to an individual mentioned disparagingly in the course of a brief, fifteen minute program. In 1974, on the other hand, a unanimous Court held unconstitutional a similar state statute compelling a privately-owned newspaper to furnish cost-free reply space to an individual mentioned disparagingly in the course of a brief editorial. ${ }^{60}$ One difference (not the only one, to be sure) was this: by statute, some decades earlier, Congress had presumed to assert national ownership over the airwaves, further providing that no person, company, or licensee could acquire any "property" in those airwaves-that, at most, they could receive a three year conditional license of use. ${ }^{61}$ In Florida, there was, of course, no equivalent statute precluding conventional private ownership of the newsprint on which the Miami Herald was printed: that ownership was complete, it carried with it full first amendment protections, and the state right-of-reply statute was correspondingly an abridgment of the newspaper's private property rights and freedom-of-speech: to exclude access by third parties.

It seems quite clear, then, that the security of private property as an extension of oneself and the corresponding liberty of free speech with respect to ownership dominion of that private property, is a clear and powerful development of the seventies. As several of these cases display, moreover, the development is very much related to the resurgence of entrepreneurial interests-a recrudescent faith in the superiority of the marketplace, limited not very much any longer by egalitarian themes from the first (or fourteenth) amendment but, rather, by the more restrained limits of the antitrust laws alone.

The importance of owning private property as the necessary-and-sufficient condition for free speech has been underscored in additional ways. As entrepreneurial prerogatives of expression have been reinvigorated, and as the contour of "state action" has been drawn back again to exempt private prop-

\footnotetext{
58. 424 U.S. 1 (1976).

59. Red Lion Broadcasting Co. v. FCC, 395 U.S. 367 (1969).

60. Miami Herald Publishing Co. v. Tornillo, 418 U.S. 241 (1974). For a comparison with Red Lion, see Van Alstyne, The Möbius Strip of the First Amendment: Perspectives on Red Lion, 29 So. CAR. L. Rev. 539 (1978).

61. See 47 U.S.C. $\$ 301(1970)$.
} 
erty from third party claims, ${ }^{62}$ the dimensions of the public forum itself have also undergone considerable revision: they have shrunk. The result is that the first amendment is geographically less applicable even to state-owned property at the end of the seventies, as it is geographically less applicable (as imposing third party speech servitudes) to privately-held property as well. At least so long as the government does not utilize its proprietary dominion over its own property to "take sides" in public controversy, it may now forbid first amendment uses more substantially than was the case ten years ago. The point is well illustrated by the Court's decision on Greer $v . S p o c k,{ }^{63}$ a 1976 decision upholding a flat handbilling ban imposed throughout a military base of enormous size, despite its crisscrossing by public roads, its germaneness as a place for the particular handbills, and the absence of incompatibility of the proposed handbilling with alternatives of more particular (but less inhibiting) regulation of mere time, place, or manner. Similarly, the 1974 decision in Lehman v. City of Shaker Heights, ${ }^{64}$ utilizing placcard space in public buses for the rental of commercial advertisements, but denying that space for political advertisements, is a decision which I believe would not have been sustained six years earlier.

Equivalently, I am much impressed with Justice Stevens's dissent in Houchins $v . K O E D,{ }^{65}$ the recent jail access case. There, the issue as the majority of the Court attempted to frame it was whether members of the institutional press could assert greater information-seeking first amendment access rights than others. But the issue, as Justice Stevens noted, was also, that, assuming an investigative journalist could not claim any special access, i.e., a greater right of access than a representative of the NAACP (which was interested in the conditions within the jail as a result of one suicide and several letters of complaint from prisoners), whether the extent of the sheriff's severe restrictions on access were adequately justified as to either. The majority did not particularly press for an adequate justification respecting the extent of the sheriff's restrictions, as neither was the matter pressed with any vigor in the courtroom, pretrial closure case of Gannet Co. $v$. DePasquale ${ }^{66}$. While that case

62. The retrenchment of "state action" which frees entrepreneurial prerogatives from constitutional constraints is evident in other areas as well. See, e.g., Flagg Brothers, Inc. v. Brooks, 436 U.S. 149 (1978); Jackson v. Metropolitan Edison Co., 419 U.S. 345 (1974) (fourteenth amendment not binding to require that heavily protected and regulated private utility observe due process). Compare Memphis Light, Gas, and Water Division v. Craft, 436 U.S. 1 (1978). See also Moose Lodge Number 107 v. Irvis, 407 U.S. 163 (1972) (private association holding one of a limited number of state-granted liquor licenses not constrained by the equal protection clause of the fourteenth amendment).

63. 424 U.S. 828 (1976). Compare Flower v. United States, 407 U.S. 197 (1972).

64. 418 U.S. 298 (1974). Compare Police Department v. Mosley, 408 U.S. 92 (1972).

65. 438 U.S. 1, 19 (1978) (Stevens, J., dissenting).

66. 99 S. Ct. 2898 (1979). 
is clearly not the last word on courtroom access, the following portion of Justice Rehnquist's concurring opinion (in Gannet) is extremely dramatic:

Despite the Court's seeming reservation of the question whether the First Amendment guarantees the public a right of access to pretrial proceedings, it is clear that ... there is no First Amendment right of access in the public or the press to judicial or other governmental proceedings. [Emphasis added] ${ }^{67}$

Greer, with related cases during the seventies, not insignificantly shrank the scope of publicly-owned property available for the exercise of free speech. Gannet, Houchins, and related cases not insignificantly restricted access to publicly-owned property which access may inform one's speech. There is in respect to each a sense of very heavy retrenchment: neither property "owned" by others nor property "owned" by the state is as widely available as decisions in the preceding decade appeared to imply ${ }^{68}$-as constitutionally accessible for the exercise of first amendment liberties. Simultaneously, the free speech claims of private property, commercial property and entrepreneurial property are more important than before.

\section{IV}

\section{The Re-emergence of Locke in the Allocation of Civil Liberties}

Thus far, our examples respecting the importance of private property as the principal fulcrum for the practical exercise of civil liberties have been confined to liberties, such as speech, that we associate with the first amendment. The same theme respecting the importance of property (who owns it, who controls access to it, what conditions may be attached to its enjoyment) is equally evident in two other sets of cases. The first relates to privacy in the strict constitutional sense, i.e., fourth amendment search warrant requirements as a condition of state intrusion. The second relates to due process before personally fateful matters are adjudicated of an individual. Both have been newly treated with distinctions of property clearly in mind: not merely whether one has it, but by what means (and on what conditions) did one acquire it?

When the property one holds is held as a presumed consequence of earnings, exchange, skill, or thrift, it comes closer to the "rightness" of deserving full protection in a distinctly Lockeian sense. Then indeed it is one's own, in evident contrast with what one holds unearned and at public sufferance. The latter, not easily defended on the basis of Locke's labor theory of (property) value, is less rightful in its entitlements. At least this point of view is evident in older cases of constitutional law-and now it has emerged once again. It ac-

67. Id. at 2918. (Rehnquist, J., concurring).

68. See, e.g., Brown v. Louisiana, 383 U.S. 131 (1966) (anteroom of public library subject to first amendment use for nondisruptive protest of alleged library policy). 
counts in part, I believe, for the difference between Wyman $v$. James ${ }^{69}$ and Marshall $v$. Barlow's Inc. ${ }^{70}$ both within this decade of the Supreme Court.

Wyman involved a warrantless search of a welfare recipient's apartment under pain of terminating public assistance if access were refused. Marshall involved a warrantless search of business premises under pain of civil fine if access were refused. In neither case was there probable cause to believe that evidence of illegal activity was to be found; in each, however, there was some reason for the government official to request access, as he did. In the first instance, it was to determine whether a welfare-assisted child was being maintained under reasonable conditions; in the second, it was to determine whether the conditions of the business premises were in compliance with standards of safety as prescribed by federal law. In the first, a majority of the Court concluded that the warrantless search could be enforced by terminating assistance if consent under duress were refused; in the second, a majority concluded that it could not be enforced under duress if consent were refused-and that a warrant would have to be secured.

A fourth amendment amenity, some kind of warrant, was constitutionally prerequisite for entry onto business premises. An equivalent amenity was not deemed constitutionally prerequisite for entry into the welfare recipient's apartment. The cases certainly cannot be reconciled on the thought that nonpublic areas of a business establishment are more protected by the fourth amendment than an apartment. ${ }^{71}$ Neither, I think, can they be reconciled on the ground that the threat of a civil fine for nonconsent was more coercive in Barlow than the threat to terminate assistance in Wyman; nor in differing degrees of cause, appropriateness, or general "reasonableness" of the time, place, or manner of the proposed search. Rather, I believe the difference relates to distinctions we have already been noting at some length. ${ }^{72}$

The Barlow case involved private property, private enterprise, and warrantless administrative intrusions to determine whether regulations are being violated on those premises. Wyman involved warrantless administrative intrusions not to determine whether the welfare recipient was operating "her" property in conformity with the law; it was to determine whether the welfare recipient was living up to the conditions the state imposed as conditions of its largess. In the former case, there is the unarticulated assumption that the intrusion

69. 400 U.S. 309 (1971).

70. 436 U.S. 307 (1978).

71. The fourth amendment (as well as the third amendment) is explicit in its application to "houses," and applicable merely by way of sensible implication to other places.

72. In what is surely one of his more trenchant dissents, Justice Marshall put the majority's "explanation" of its analysis in Wyman v. James as follows:

We are told that there is no search involved in this case; that even if there were a search, it would not be unreasonable; and that even if this were an unreasonable search, a welfare recipient waives her right to object by accepting benefits. I emphatically disagree with all three conclusions.

400 U.S. at 338 (Marshall, J., dissenting). 
needs greater justification than in the latter case-the greater justifications demanded to interfere with private property acquired by thrift, exchange, labor, or skill. Never mind that the fourth amendment does not, on its face, express that distinction. Never mind, either, that an apartment may be a more intimate precinct of personal sanctuary than the nonpublic portions of business premises. The antecedents of the fourth amendment are subconsciously drawn upon-and they, quite emphatically, are assumed to express that distinction: privacy within property acquired without aid of the state is a basic civil liberty; privacy with respect to incidents of state aid is not.

Something akin to this distinction is evidently also at work in the Supreme Court's jurisprudence of procedural due process as well. Prior to 1972 , the extent to which grievous personal loss was buffered by procedural due process depended most of all on the supposed importance of the threatened loss. Since 1972, however, even "grievous loss" is not subject to any due process requirements of one who cannot locate some vested private property in the thing thus threatened. These cases and their doctrines have been thoroughly reviewed elsewhere. ${ }^{73}$ Here, it should be sufficient simply to note that they complete the cycle of emphasis most notable of the seventies: the "old" property (private property) has received additional fortification under the Constitution through its liberty clauses as well as through its commercial clauses; the "new" property (access and status interests in the public sector) has all but succumbed.

\section{$\mathrm{V}$ \\ Conclusion}

In the second quotation that I chose to preface this brief review, the Supreme Court identified a crucial interdependence "between the personal right to liberty and the personal right in property." It declared further that " $t]$ he right to enjoy property" is "no less than the right to speak or the right to travel;" that, indeed, "rights in property are basic civil rights. [emphasis added] ${ }^{74}$ John Locke would certainly have approved, and the Constitution is, in part, the very enactment of John Locke's Second Treatise on Civil Government. A great number of the Court's decisions during the past decade have been concerned to restore that connection-and they have.

At the same time, this Court has tended, perhaps inadvertently, to overfulfill the very thoughtful jurisprudence of John Locke. Ironically, its de-

\footnotetext{
73. See cases and references in Van Alstyne, Cracks in "The Property:" Adjudicative Due Process in the Administrative State, 62 Cornell L. Rev. 445 (1977). The California Supreme Court has recently rejected the U.S. Supreme Court's "property" distinction, proceeding on the adequate and independent basis of the California Constitution. The California Supreme Court identifies "freedom from arbitrary adjudicative procedures" as "a substantive element of one's liberty," thus putting it beyond the capacity of government to avoid furnishing any due process whatever through the expedient of defining "property." See People v. Ramirez, 158 Cal. Rptr. 316,321 (1979).
}

74. Lynch v. Household Finance Corp., 405 U.S. 538, 552 (1972). 
cisions have thus made the connection between private property and personal liberty something of a self-fulfilling prophecy. They have done so by contributing to the certainty that those without personal rights in property have only the weakest and most tenuous claim to personal liberties-whether of speech, of privacy, or of due process of law. The Court's decisions now enable the government to be less generous than it was once required to be in respect to public property and liberty, even as they have also restored to private owners exclusionary prerogatives and entitlements of use that leave those without property of their own dramatically unequal in the possession of their more meager liberties.

Simultaneously, as Professor Grey outlines in his paper, ${ }^{75}$ this Court also has been overall less tolerant of sheltering personal liberties offensive to majoritarian morality or conventional virtue, and even here its disposition displays a preference for the values of (middle-class) "property."78 Commercial speech is newly protected; scatological utterances are newly censurable. Reputation has its compensable claims in renewed possibilities for large libel actions; speech must be correspondingly more carefully weighed, considered, and researched. ${ }^{77}$ "Liberty" is less lively, less spacious, and a little less shared than in the decade preceding the seventies-the uses of that liberty are bound more tightly than before to the importance of property as an essential condition of its free exercise. The net effect is not that there is necessarily less constitutionally-protected liberty overall than there was a decade ago, but that that liberty has been reapportioned in ways that confirm the value of private property.

75. Grey, Eros, Civilization and the Burger Court, 43:3 Law \& Contemp. Prob. 83 (1980).

76. See notes 3 and 8, supra.

77. See note 6, supra. 